\title{
A model of chronic IgE-mediated food allergy in ovalbumin-sensitized mice
}

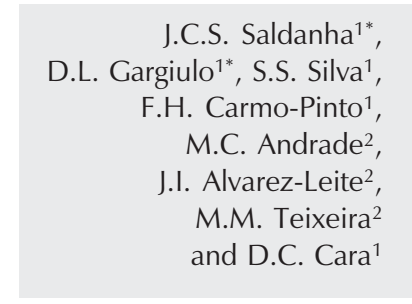

\author{
Departamentos de ${ }^{1}$ Patologia Geral and ${ }^{2}$ Bioquímica e Imunologia, \\ Instituto de Ciências Biológicas, Universidade Federal de Minas Gerais, \\ Belo Horizonte, MG, Brasil
}

\section{Correspondence \\ D.C. Cara \\ Av. Antônio Carlos, 6627 \\ Departamento de Patologia Geral \\ ICB, UFMG \\ 31270-901 Belo Horizonte, MG \\ Brasil}

Research supported by FAPEMIG, CAPES and CNPq.

*These authors contributed equally to this study.

Received June 2, 2003

Accepted February 10, 2004

\begin{abstract}
Food allergy is most frequently the result of IgE-mediated hypersensitivity reactions. Here, we describe a chronic model in which some of the intestinal and systemic consequences of continuous egg white solution ingestion by ovalbumin-sensitized eight-week-old BALB/c mice, 6 animals per group, of both sexes, were investigated. There was a $20 \%$ loss of body weight that began one week after antigen exposure and persisted throughout the experiment ( 3 weeks). The sensitization procedure induced the production of anti-ovalbumin IgG1 and IgE, which were enhanced by oral antigen exposure $(129 \%$ for IgG1 and $164 \%$ for IgE, compared to sensitization values). Intestinal changes were determined by jejunum edema at $6 \mathrm{~h}(45 \%$ Evans blue extravasation) and by a significant eosinophil infiltration with a peak at $48 \mathrm{~h}$. By day 21 of continuous antigen exposure, histological findings were mild, with mast cell hyperplasia (100\%) and increased mucus production $(483 \%)$. Altogether, our data clearly demonstrate that, although immune stimulation was persistently occurring in response to continuous oral antigen exposure, regulatory mechanisms were occurring in the intestinal mucosa, preventing overt pathology. The experimental model described here reproduces the clinical and pathological changes of mild chronic food allergy and may be useful for mechanistic studies of this common clinical condition.
\end{abstract}

\section{Introduction}

The physiological penetration of dietary macromolecules into the organism through the gut mucosa has several recognized immunological consequences. One of these is the development of food allergy, which is defined as an adverse immunological (hypersensitivity) response to food and can be
Key words

- Food allergy

- Ovalbumin

- Murine model

- IgE

- Hypersensitivity 
height and weight (3). Food allergy and other types of allergies, such as allergic rhinitis and asthma, are reaching epidemic proportions in both the developed and developing countries (4). The reasons for the changes in prevalence of allergic disorders are not known and several hypotheses have been raised to explain them, including the "hygiene hypothesis", which states that a reduction in infections in early infancy predisposes to allergic responses $(5,6)$. The understanding of regulatory mechanisms controlling allergic inflammation may provide useful insights into disease pathophysiology and aid in the development of novel therapeutic strategies.

We have reported that mice previously sensitized against ovalbumin (Ova) avoided the ingestion of a sweetened solution of egg white, choosing water instead $(7,8)$, and this aversion was related to $\operatorname{IgE}$ antibodies (9). Indeed, elimination diet is still the mainstay of IgE-dependent food allergy therapy $(2,3)$. However, with the advent of manufactured food, trace amounts of allergens can still be present in food and some atopic patients appear to be continuously exposed to these allergens. In these atopic patients, continuous unwilling exposure to a food allergen may induce a mild and persistent allergic condition. To try mimicking the latter clinical situation, we have developed an experimental model in which sensitized mice are given egg white solution (EWS) as the only liquid source.

\section{Material and Methods}

Animals

Young adult BALB/c mice of both sexes were used. All mice received standard (Purina) mouse chow throughout the experiment. All investigations were in agreement with the Ethical Principles in Animal Experimentation, adopted by the Ethics Committee in Animal Experimentation of our Institution (CETEA/UFMG).

\section{Sensitization protocol}

Mice received (day 0) a subcutaneous (sc) injection of $0.2 \mathrm{ml}$ saline containing 10 $\mu \mathrm{g}$ Ova (five times crystallized hen's egg albumin; Sigma, St. Louis, MO, USA) plus 1 $\mathrm{mg} \mathrm{Al}(\mathrm{OH})_{3}$ as adjuvant. Secondary sensitization consisted of a $s c$ injection of $10 \mu \mathrm{g}$ soluble Ova 14 days after the primary sensitization (day 14). Although it has been shown that intraperitoneal injection of alum induces higher antibody production (10), we chose the $s c$ route to avoid peritoneal inflammation. Seven days after the secondary sensitization (i.e., on day 21), the bottle containing tap water was replaced with gauze filtered $20 \%$ EWS for a period of 3 weeks (from day 21 to day 42). This solution contains about $10 \mathrm{mg} \mathrm{Ova} / \mathrm{ml}$. The following control groups were studied in parallel for comparison: nonsensitized or sensitized mice that were given tap water throughout the experimental procedure and non-sensitized mice that were given EWS from day 21 to day 42 .

\section{Nutritional status}

In order to evaluate the nutritional condition of all animals, liquid and food consumption and body weight were determined each week. After 21 days of continuous EWS ingestion, hematocrit levels were determined and serum albumin levels were measured using an Albumin Doles Kit (Goiania, GO, Brazil) in order to assess the possible presence of dehydration and/or malnutrition.

\section{Serum antibodies}

Serum samples were obtained from groups culled weekly after oral antigen exposure for the measurement of anti-Ova IgG1 and IgE. The ELISA test for IgG1 was carried out using plates coated with Ova, $100 \mu 1$ of a 1:1600 dilution of mouse sera and biotinylated goat anti-mouse IgG1 (Southern Biotechnology Associates, Birmingham, AL, 
USA). The reactions were developed with the streptavidin-peroxidase conjugate (ExtraAvidin; Sigma), o-phenylene-diamine and $\mathrm{H}_{2} \mathrm{O}_{2}$. The plates were read at $492 \mathrm{~nm}$ on an automated ELISA reader (EL800, Bio-Tek Instruments, Inc., Winooski, VT, USA). AntiOva $\operatorname{IgE}$ antibodies were measured by capture-ELISA using plates coated with rat antimouse IgE and $50 \mu \mathrm{l}$ total serum and biotinylated Ova, as previously described (11). The results are reported as arbitrary units using a positive reference serum assigned to be 1000 units.

\section{Intestinal edema}

Vascular permeability changes were evaluated by Evans blue dye extravasation (12). Twenty-one days after the primary sensitization with $10 \mu \mathrm{g}$ Ova $+1 \mathrm{mg} \mathrm{Al}(\mathrm{OH})_{3}$, the animals were exposed to a restricted and voluntary intake of EWS for 6, 24 and $48 \mathrm{~h}$ and then injected with Evans blue $(20 \mathrm{mg} /$ $\mathrm{kg}$ ) into the tail vein; 10 min later, the animals were killed and the small intestine was dissected and weighed. The intestine was divided into four segments (duodenum, proximal jejunum, distal jejunum, and ileum) and each segment was further divided into two parts. One was soaked in formamide $(4 \mathrm{ml} / \mathrm{g}$ wet weight tissue at $20^{\circ} \mathrm{C}$ for $24 \mathrm{~h}$ ) to extract the Evans blue dye, and the other was dried at $60^{\circ} \mathrm{C}$ for $24 \mathrm{~h}$. The concentration of Evans blue was determined by spectrophotometry at $630 \mathrm{~nm}$ using an ELISA reader (EL800, Bio-Tek Instruments) and 96-well plates. Results were plotted on a standard curve for Evans blue $(0.15-20 \mu \mathrm{g} / \mathrm{ml})$. The Evans blue content of each sample is reported as $\mathrm{mg} / \mathrm{g}$ dry weight tissue.

\section{Histology and morphometry}

Changes in the intestinal mucosa were evaluated at 6,24 and $48 \mathrm{~h}$, and at 7,14 and 21 days of the experiment. The mice were sacrificed by cervical dislocation and the small intestine was taken for histological analysis. The intestine was divided into four segments (duodenum, proximal jejunum, distal jejunum, and ileum), fixed in $10 \%$ formalin in PBS, embedded in paraffin and cut into $3-5-\mu \mathrm{m}$ thick sections. The sections were stained with hematoxylin-eosin for general analysis, with Toluidine blue for mast cell evaluation, with periodic acid Schiff for mucus analysis, or with $1 \%$ carbol chromotrope 2R and hematoxylin (Sigma) for eosinophil granule identification.

As described elsewhere, the intestinal mucosa was submitted to morphometric analysis using an image analysis program running on an IBM computer (13). Images were obtained with a JVC TK-1270/RGB microcamera and the KS300 software built in a Kontron Eletronick/Carl Zeiss image analyzer. Ten fields from hematoxylin-eosinstained sections were randomly chosen at 10X (871.392 $\mu \mathrm{m}^{2} /$ field $)$ for villus height and crypt depth measurement. Ten fields were chosen randomly at $40 \mathrm{X}\left(53.333 \mu \mathrm{m}^{2} /\right.$ field) from chromotrope and Toluidine blue sections in order to count the number of eosinophils and mast cells, respectively, and the data are reported as number of cells/ field. For the determination of goblet cell volume, all pixels with green hues were selected for the creation of a binary image and subsequent calculation of the total area, and the data are reported as $\mu \mathrm{m}^{2}$ mucus/field.

\section{Statistical analysis}

Data were analyzed statistically by oneway analysis of variance (ANOVA) or by the Student $t$-test, when appropriate, with the level of significance set at $\mathrm{P}<0.05$. If ANOVA revealed differences, the groups were compared by the Student $t$-test with Bonferroni correction. The data shown in the Figures are reported as means \pm SEM for 6 animals per group. In the text, the data are reported as means \pm SD for 6 animals per group $(\mathrm{N})$ or as the range for all groups. 
Figure 1. Body weight of mice up to 42 days after the first sensitization with ovalbumin (Ova). Data are reported as means \pm SEM in $g$ for 6 mice in each group. BALB/c mice received $\left(\mathrm{Ova}^{+}\right)$or not $\left(\mathrm{Ova}^{-}\right) 10 \mu \mathrm{g}$ Ova plus $\mathrm{Al}(\mathrm{OH})_{3}$ on day 0 and $10 \mu \mathrm{g}$ Ova on day 14. From day 21 to the end, some $\mathrm{Ova}^{+}$and Ovaanimals received filtered $20 \%$ $(w / v)$ egg white solution in their drinking bottle $\left(E_{W S}^{+}\right)$. ${ }^{*} P<$ 0.05 compared to $\mathrm{Ova}^{-} / \mathrm{EWS}^{+}$ (ANOVA-Student $t$-test). $\lg 1$ and $\lg E$ levels of mice senbody responses of BALB/c mice sensitized with $10 \mu \mathrm{g}$ Ova plus $\mathrm{Al}(\mathrm{OH})_{3}$ on day 0 and with $10 \mu \mathrm{g}$ Ova on day 14. From day 21 to the end, some $\mathrm{Ova}^{+}$and $\mathrm{Ova}^{-}$ animals received filtered $20 \%$ egg white solution in their drinking bottle $\left(E S^{+}\right)$. Data are reported as means \pm SEM of IgG1 and IgE expressed as arbitrary ELISA units for 6 animals per group. ${ }^{*} P<0.05$ compared to $\mathrm{Ova}^{-} / \mathrm{EWS}^{-}$, and ${ }^{* *} \mathrm{P}<0.05 \mathrm{com}-$ pared to $\mathrm{Ova}^{+} / \mathrm{EWS}^{-}$(ANOVAStudent $t$-test).
Figure 2. Anti-ovalbumin (Ova) sitized with Ova. Serum anti-
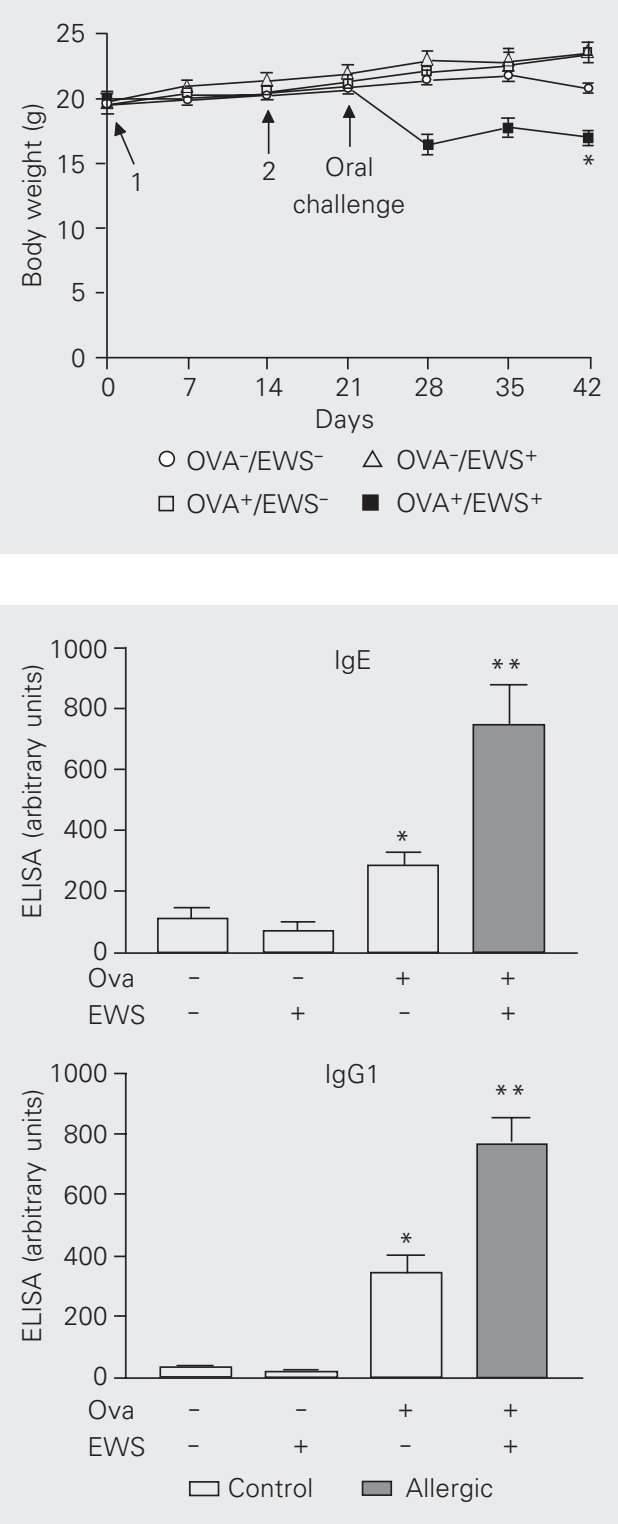

Figure 3. Intestinal vascular permeability. Extravasation of Evans blue dye in the small intestine (D - duodenum, PJ - proximal jejunum, DJ - distal jejunum, I ileum) triggered by oral challenge with egg white solution (EWS) during a period of $6 \mathrm{~h}$ by sensitized $\left(\mathrm{Ova}^{+}\right)$(closed bars) and non-sensitized $\left(\mathrm{Ova}^{-}\right)$(open bars) mice. Animals were sensitized 21 days before the challenge by an injection of $10 \mu \mathrm{g}$ OVA plus $1 \mathrm{mg} \mathrm{Al}(\mathrm{OH})_{3}$. Data are reported as means \pm SEM of Evans blue/g tissue for 6 animals per group. ${ }^{*} P<0.05$ compared to control Ova-/EWS ${ }^{+}$(ANOVA-Student $t$-test).

\section{Results}

The mean daily tap water consumption was similar for sensitized $(4.7 \pm 0.2 \mathrm{ml})$ and non-sensitized $(4.2 \pm 0.2 \mathrm{ml})$ mice, whereas the mean daily EWS consumption was higher for non-sensitized mice $(8.3 \pm 0.8 \mathrm{ml}) \mathrm{com}$ pared to sensitized mice $(4.1 \pm 0.4 \mathrm{ml})$. All groups showed the same food consumption (data not shown). One week after the oral challenge with EWS, sensitized, but not nonsensitized, mice had lost about $20 \%$ of their body weight (Figure 1). The loss of body weight was maintained throughout the observation period and was not observed in animals who ingested tap water (Figure 1). The decreased body weight appeared not to be related to dehydration since there were no significant differences in hematocrit levels among groups (48-54\%). Likewise, serum albumin levels were similar among groups before and after oral exposure to EWS or water $(3.4-3.7 \mathrm{~g} / \mathrm{dl})$.

The sensitization procedure by itself induced the production of both anti-Ova IgG1 and IgE (Figure 2). Remarkably, the concentration of both of these antibodies more than doubled in sensitized mice that were given EWS solution, but not in sensitized mice given tap water (Figure 2). EWS consumption did not affect circulating levels of immunoglobulins in non-sensitized mice (Figure 2).

Twenty-one days after Ova sensitization, mice were exposed to restricted and voluntary EWS for $6 \mathrm{~h}$. During this time, they ingested about $0.8 \mathrm{ml}$ of the solution ( $8 \mathrm{mg}$ Ova) and developed an increase in the vascular permeability of the proximal segments of the small intestine (Figure 3), as shown by the extravasation of Evans blue dye. There were no statistical differences in dye extravasation among the control groups at $6 \mathrm{~h}$, or among all groups at later time points (data not shown). However, the early increase in vascular permeability generated villus swelling $24 \mathrm{~h}$ after EWS ingestion in sensitized mice (Figure 4B).

Inflammatory cell infiltration, with an 
evident presence of eosinophils (Figure 4C), was seen as early as $6 \mathrm{~h}$ after antigen exposure. However, the number of eosinophils in the jejunal mucosa peaked at $48 \mathrm{~h}$ after antigen exposure and dropped thereafter (Figure 5A). Nevertheless, eosinophils were still present at significantly higher levels than in control animals until the end of the observation period (day 21).

With the continuous exposure to antigen (about $47 \mathrm{mg}$ Ova/day), the pathological changes markedly improved and, at 21 days after oral antigen exposure, the intestine showed no edema and little infiltration of inflammatory cells other than eosinophils. However, there was increased mucus production by goblet cells (Figures 4D and 5B) and mast cell hyperplasia (Figures $4 \mathrm{E}$ and 5C) in the jejunum. The total mucosa height did not differ from control (Figure 5D).

No morphological differences were seen in any segment of the small intestine of nonsensitized mice given water or EWS or of sensitized mice given water when compared to the intestine of naive mice.
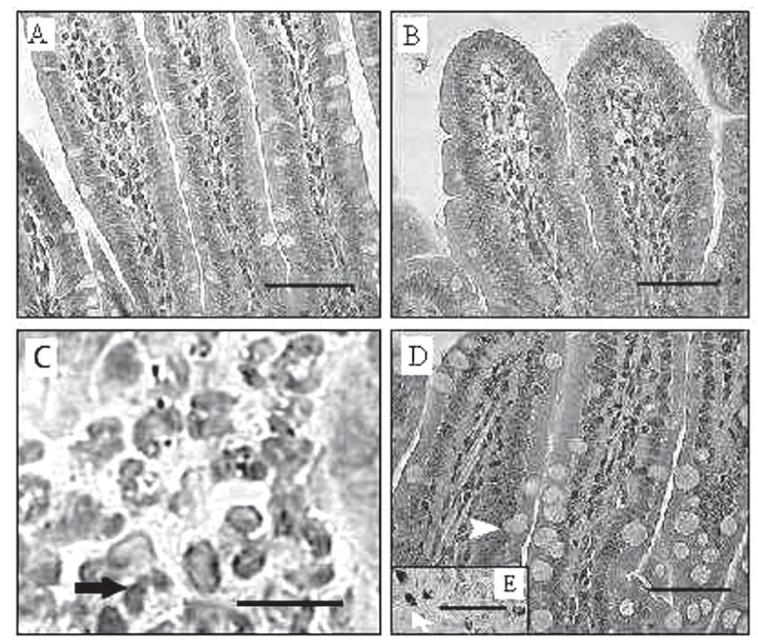

Figure 4. Representative histological sections of the proximal jejunum from non-sensitized mice drinking water (A), and from sensitized mice after $24 \mathrm{~h}(\mathrm{~B}), 48 \mathrm{~h}(\mathrm{C})$ and 21 days $(D, E)$ of continuous ingestion of a filtered $20 \%$ egg white solution. A, B and D, hematoxylin and eosin staining; C, chromotrope 2R staining; $E$, Toluidine blue staining. The bars are $50 \mu \mathrm{m}$ in $A, B, D$ and $E$, and the bar in $C$ is $25 \mu \mathrm{m}$. The large arrow in $\mathrm{C}$ indicates an eosinophil, the small white arrow in $\mathrm{E}$ indicates a mast cell, and the white arrowhead in $\mathrm{D}$ indicates a goblet cell.
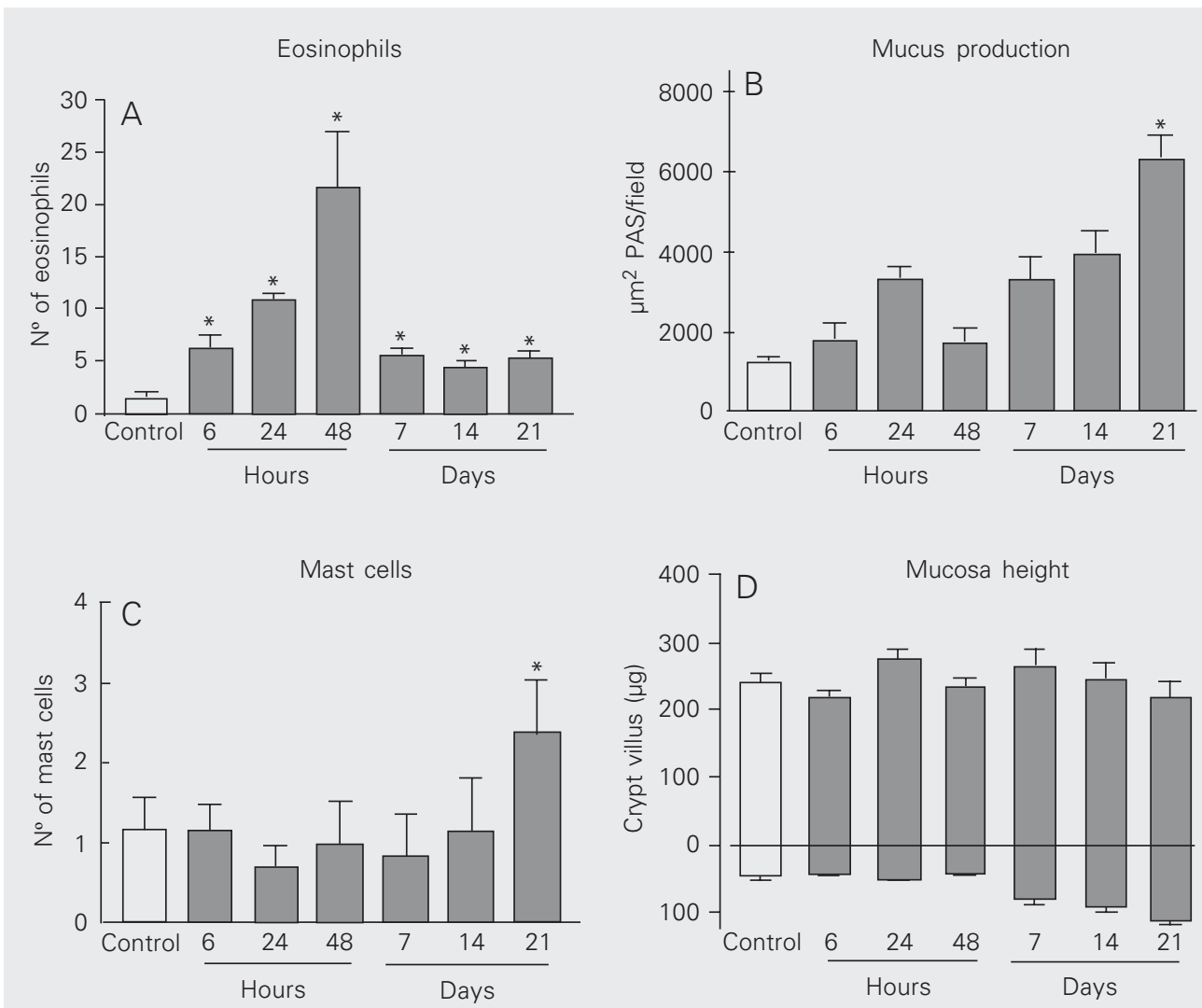

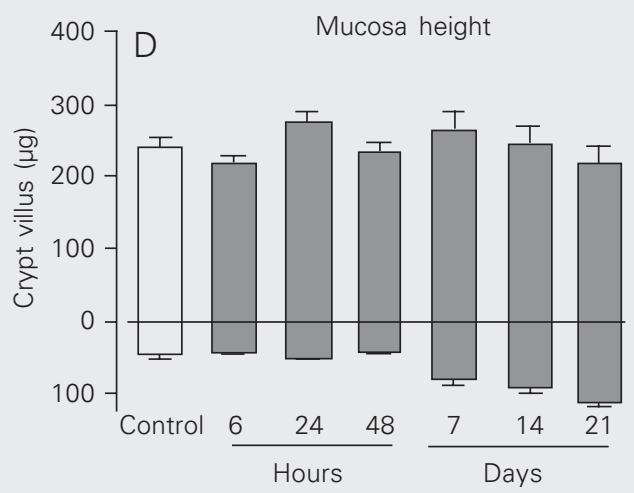

Figure 5. Eosinophils (A), mucus production (B), mast cells (C), and mucosa height (D) in the jejunum of BALB/c mice sensitized with $10 \mu \mathrm{g}$ ovalbumin (OVA) plus $1 \mathrm{mg} \mathrm{Al}(\mathrm{OH})_{3}$ after continuous ingestion of an egg white solution (EWS). The open bars indicate the control group (Ova-/EWS') and the closed bars represent the allergic group $\left(\mathrm{Ova}^{+} / \mathrm{EWS}^{+}\right)$who ingested the EWS. Data are reported as means \pm SEM of number of cells $(A, C)$, mucus production (B; PAS = periodic acid Schiff), or mucosa height (D) for 6 mice in each group ${ }^{*} \mathrm{P}<0.05 \mathrm{com}$ pared to control Ova-/EWS ${ }^{-}$ (ANOVA-Student $t$-test). 


\section{Discussion}

There is much experimental evidence showing that the introduction of antigens via the gastrointestinal route induces oral tolerance, defined as the inhibition of specific antibody formation after subsequent parenteral immunizations with the same antigen (14). However, our results suggest that, when mice are sensitized to OVA, the subsequent long-term, low-level exposure to this same antigen via the oral route serves as an immunological booster leading to high levels of $\mathrm{IgE}$ and $\mathrm{IgG1}$ production. Indirectly, these experiments suggest that a small portion of the ingested antigen is indeed capable of transposing the gut barrier and stimulating primed lymphocytes. Usually, IgE-dependent food allergy reactions affect one or more target organs such as skin, respiratory tract, gastrointestinal tract, and cardiovascular system (2). An immediate systemic reaction mediated by $\mathrm{IgE}$ is called anaphylaxis irrespective of severity (15), but colloquially the term anaphylaxis is applied to severe, potentially fatal allergic reactions (2). Mainly in children, chronic food allergic disorders (IgEassociated) typically affect the gastrointestinal tract with different degrees of eosinophilic inflammation, edema and weight loss (16).

Sensitized mice showed the same consumption of egg white and tap water, but the consumption of egg white by non-sensitized mice was higher than that by sensitized animals. The latter result suggests that there was an aversion to EWS by sensitized mice. This immunologically taste aversion was documented before $(7,8)$ and was related to IgE responses (9). Recently, Basso and coworkers (17) have shown that after an oral Ova challenge, allergic mice presented higher levels of anxiety, increased Fos expression in emotionality related brain areas, and also aversion to Ova-containing solution. In our model, after prolonged egg white consumption, sensitized mice also showed a marked loss in body weight. The mechanisms involved in this phenomenon are not clear, although this event has also been observed in rat models $(18,19)$. Although the hematocrit and serum albumin levels were normal, suggesting that dehydration and/or malnutrition did not occur in mice with food allergy, we cannot exclude the possibility that a decreased absorption of other diet components or an increased energy consumption may have occurred. It is possible that the mechanisms involved in body weight loss are related to food aversion. By day 21, body weight was still low and circulating IgE and IgG1 levels were highest. These responses were related to the genetic background, since when another lineage was used (C57BL6), sensitization induced the production of $\operatorname{IgE}$, but at lower levels when compared to BALB/c mice and there was no loss in body weight (data not shown). Also, our preliminary data have shown that IL-4 receptor alpha-deficient $\mathrm{BALB} / \mathrm{c}$ mice do not produce IgE when immunized, nor do they lose body weight when challenged. These results indicate that this model is strongly related to Th2 cytokines.

After $6 \mathrm{~h}$ of antigen intake, vascular permeability was increased, as detected histologically at $24 \mathrm{~h}$. This acute inflammatory change may be a result of local mast cell degranulation in response to Ova challenge and of the subsequent increase of histamine levels in the gut, as has observed elsewhere in sensitized mice after Ova challenge (20). In chronic allergic diseases such as asthma, during continuous antigen exposure eosinophils are primed by IL-5 and attracted by chemokines, infiltrating the tissue (21). These cells are responsible for the late phase of the immediate allergic reaction, producing basic protein which is toxic to the epithelium (21). Particularly in the jejunum, we observed that an eosinophil infiltrate was present as early as $6 \mathrm{~h}$ after exposure, with a peak at $48 \mathrm{~h}$ followed by low but significant levels until the end of the experiment.

With continuous exposure to the antigen, 
pathological changes were marked by goblet cell and mast cell hyperplasia. Mast cell numbers in tissues are relatively constant, even though mast cell hyperplasia is observed in both the inflammatory and in the repair/remodeling stage of various inflammatory/fibrotic disorders (22). The functional significance of the accumulation of mast cells in these processes is largely unknown. In allergy, apart from their classical role in eliciting the early phase, mast cells also have an important function in late and chronic stages (23). In these stages they may interact with and be activated by infiltrated inflammatory cells such as eosinophils and lymphocytes and by resident structural cells such as epithelial and smooth muscle cells and fibroblasts.

Mucus hypersecretion is another characteristic of allergic inflammation and has been shown to be IL-13 dependent (24). It has been proposed that mucus protects the intes- tinal wall by limiting the absorption of antigens (25).

Taken together, our data clearly demonstrate that, although immune stimulation was persistently occurring in response to continuous oral antigen exposure, regulatory mechanisms in the intestinal mucosa prevented overt pathology. The mechanisms underlying the regulation of intestinal pathology in the model were not investigated here but clearly deserve further study. Moreover, it will be important to determine whether regulatory events triggered by chronic oral antigen exposure are antigen specific and restricted to the intestinal mucosa. The model of food allergy described here can be important to answer the questions raised above and may permit further understanding of the functional relevance of regulatory events triggered by chronic oral antigen exposure in allergic individuals.

\section{References}

1. Sampson HA (1999). Food allergy. Part 1: immunopathogenesis and clinical disorders. Journal of Allergy and Clinical Immunology, 103: 717-728.

2. Sicherer SH (2002). Food allergy. Lancet, 360: 701-710.

3. Christie L, Hine RJ, Parker JG \& Burks W (2002). Food allergies in children affect nutrient intake and growth. Journal of the American Dietetic Association, 102: 1648-1651.

4. Holgate ST (1999). The epidemic of allergy and asthma. Nature, 402: B2-B4.

5. Yazdanbakhsh M, Kremsner PG \& van Ree R (2002). Allergy, parasites, and the hygiene hypothesis. Science, 296: 490-494.

6. Helm RM \& Burks AW (2000). Mechanisms of food allergy. Current Opinion in Immunology, 12: 647-653.

7. Cara DC, Conde AA \& Vaz NM (1994). Immunological induction of flavor aversion in mice. Brazilian Journal of Medical and Biological Research, 27: 1331-1341.

8. Cara DC, Conde AA \& Vaz NM (1997). Immunological induction of flavour aversion in mice. II. Passive/adoptive transfer and pharmacological inhibition. Scandinavian Journal of Immunology, 45: 16-20.

9. Andrade MC (1999). Participação do processo anafilático na aversão à ingestão de clara de ovo por animais imunizados com ovalbumina. Master's thesis, Departamento de Bioquímica e Imunologia, Universidade Federal de Minas Gerais, Belo Horizonte, MG, Brazil.

10. Faquim-Mauro EL \& Macedo MS (2000). Induction of IL-4-dependent, anaphylactic-type and IL-4-independent, non-anaphylactic-type IgG1 antibodies is modulated by adjuvants. International Immunology, 12: 1733-1740.
11. Russo M, Nahori MA, Lefort J et al. (2000). Suppression of asthmalike responses in different mouse strains by oral tolerance. American Journal of Respiratory Cell and Molecular Biology, 24: 518-526.

12. Jancar S, Sirois MG, Carrier J, Braquet P \& Sirois P (1991). PAF induces rat plasma extravasation and releases eicosanoids during anaphylaxis. Inflammation, 15: 347-354.

13. Ramos MG, Bambirra EA, Cara DC, Vieira EC \& Alvarez-Leite JI (1997). Oral administration of short-chain fatty acids reduces the intestinal mucositis caused by treatment with Ara-C in mice fed commercial or elemental diets. Nutrition and Cancer, 28: 212-217.

14. Mowat A \& Weiner HL (1999). Oral tolerance. Physiological basis and clinical applications. In: Ogra P, Mestecky J, Lamm M, Strober W, Bienenstock J \& McGheee J (Editors). Mucosal Immunology. Academic Press, San Diego, CA, USA.

15. Joint Task Force on Practice Parameters, American Academy of Allergy, Asthma and Immunology, American College of Allergy, Asthma and Immunology, and the Joint Council of Allergy, Asthma and Immunology (1998). The diagnosis and management of anaphylaxis. Journal of Allergy and Clinical Immunology, 101: S456-S528.

16. Sampson HA, Sicherer SH \& Birnbaum AH (2001). AGA technical review on the evaluation of food allergy in gastrointestinal disorders. Gastroenterology, 120: 1026-1040.

17. Basso AS, Pinto FA, Russo M, Britto LR, de Sa-Rocha LC \& Palermo Neto J (2003). Neural correlates of IgE-mediated food allergy. Journal of Neuroimmunology, 140: 69-77.

18. Curtis GH, Patrick MK, Catto-Smith AG \& Gall DG (1990). Intestinal anaphylaxis in the rat. Effect of chronic antigen exposure. Gastroen- 
terology, 98: 1558-1566.

19. Huneau J-F, Coste M \& Tome D (1991). Effect of chronic antigen exposure in growth and intestinal histamine content of sensitized rats. Gastroenterologie Clinique et Biologique, 15: 525-528.

20. van Halteren AGS, van der Cammen MJF, Biewenga J, Savelkoul HFJ \& Kraal G (1997). IgE and mast cell responses on intestinal allergen exposure: A murine model to study the onset of food allergy. Journal of Allergy and Clinical Immunology, 99: 94-99.

21. Cara DC, Negrao-Correa D \& Teixeira MM (2000). Mechanisms underlying eosinophil trafficking and their relevance in vivo. Histology and Histopathology, 15: 899-920.

22. Bischoff SC \& Sellge G (2002). Mast cell hyperplasia: Role of cytokines. International Archives of Allergy and Immunology, 127: 118-
122.

23. Pawankar R, Yamagishi S, Takizawa R \& Yagi T (2003). Mast cell-lgE and mast cell-structural cell interactions in allergic airway disease. Current Drug Targets in Inflammation and Allergy, 2: 303-312.

24. Zimmermann N, Hershey GK, Foster PS \& Rothemberg ME (2003). Chemokines in asthma: cooperative interaction between chemokines and IL-13. Journal of Allergy and Clinical Immunology, 111: 227-242.

25. Sanderson IR \& Walker WA (1994). Mucosal barrier. In: Ogra PL, Lamm ME, McGhee JR, Mestecky J, Strober W \& Bienenstock J (Editors), Handbook of Mucosal Immunology. Academic Press, New York. 